\title{
Triclopyr Reduces Foliar Bleaching from Mesotrione and Enhances Efficacy for Smooth Crabgrass Control by Altering Uptake and Translocation
}

\author{
Jialin Yu and Patrick E. McCullough*
}

Turfgrass managers can reduce foliar bleaching of smooth crabgrass from mesotrione by tank-mixing triclopyr ester with applications. These tank mixtures also have potential to enhance smooth crabgrass control compared to mesotrione alone. The objectives of this research were to evaluate the influence of triclopyr on the efficacy, absorption, and translocation of mesotrione in multitiller smooth crabgrass. In field experiments, tank-mixing triclopyr at 560 or $1,120 \mathrm{~g}$ ae ha ${ }^{-1}$ with mesotrione at $140 \mathrm{~g} \mathrm{ai} \mathrm{ha}^{-1}$ applied sequentially or at $280 \mathrm{~g} \mathrm{ha}^{-1}$ applied singly provided excellent control (>90\%) of multitiller smooth crabgrass in tall fescue. These treatments were more effective than mesotrione alone and fenoxaprop at $195 \mathrm{~g}_{\text {ai ha }}{ }^{-1}$ that averaged 66 and $81 \%$ control after 6 wk, respectively. Mesotrione alone at $280 \mathrm{~g} \mathrm{ha}^{-1}$ bleached smooth crabgrass $53 \%$ at 2 wk after initial treatment (WAIT), and was $14 \%$ greater than the $140 \mathrm{~g} \mathrm{ha}^{-1}$ treatment. Sequential treatments of the low mesotrione rate bleached smooth crabgrass 16 to $22 \%$ from 3 to 5 WAIT. Triclopyr tank mixtures reduced smooth crabgrass bleaching from mesotrione on all dates to $<5 \%$. Tall fescue injury was not detected at any evaluation date. In laboratory experiments, smooth crabgrass reached peak foliar absorption of ${ }^{14} \mathrm{C}$-mesotrione at 24 and $168 \mathrm{~h}$ after treatment (HAT; 23\% and 15\%) when mesotrione was applied with triclopyr at 1,120 and $0 \mathrm{~g} \mathrm{ha}^{-1}$, respectively. Triclopyr reduced translocation of radioactivity $12 \%$ at 72 and $168 \mathrm{HAT}$, compared to ${ }^{14} \mathrm{C}$-mesotrione alone. Enhanced foliar uptake of mesotrione from triclopyr tank mixtures might improve control of multitiller smooth crabgrass compared to mesotrione alone. Reduced foliar bleaching from triclopyr is associated with less translocation of mesotrione or derivatives in smooth crabgrass.

Nomenclature: Smooth crabgrass, Digitaria ischaemum (Schreb.) Schreb ex. Muhl.; tall fescue, Festuca arundinacea Shreb. 'Titan'.

Key words: HPPD, synthetic auxin, translocation, uptake.

\begin{abstract}
Profesionales en céspedes pueden reducir el blanqueamiento foliar de Digitaria ischaemum generado por la acción de mesotrione con aplicaciones de mezclas en tanque con triclopyr ester. Estas mezclas en tanque también tienen el potencial de mejorar el control de $D$. ischaemum al compararse con mesotrione solo. Los objetivos de esta investigación fueron evaluar la influencia de triclopyr sobre la eficacia, absorción, y translocación de mesotrione en D. ischaemum en el estadio de múltiples hijuelos. En experimentos de campo, las mezclas en tanque con triclopyr a 560 ó $1,120 \mathrm{~g}^{\mathrm{ae} \mathrm{ha}} \mathrm{ha}^{-1} \mathrm{con}$ mesotrione a $140 \mathrm{~g}$ ai ha ${ }^{-1}$ aplicados secuencialmente o a $280 \mathrm{~g} \mathrm{ha}^{-1}$ aplicados solos brindaron un control excelente $(>90 \%)$ de $D$. ischaemum en el estadio de hijuelos múltiples en el césped Festuca arundinacea. Estos tratamientos fueron más efectivos que mesotrione solo y fenoxaprop a $195 \mathrm{~g} \mathrm{ha}^{-1}$, los cuales promediaron 66 y $81 \%$ de control después de 6 semanas, respectivamente. Mesotrione solo a $280 \mathrm{~g} \mathrm{ha}^{-1}$ blanqueó D. ischaemum $53 \%$ a 2 semanas después del tratamiento inicial (WAIT), y fue $14 \%$ mayor que el tratamiento con $140 \mathrm{~g} \mathrm{ha}^{-1}$. Los tratamientos secuenciales de la dosis baja de mesotrione blanquearon $D$. ischaemum 16 a $22 \%$ de 3 a 5 WAIT. Las mezclas en tanque con triclopyr redujeron el blanqueamiento de $D$. ischaemum causado por mesotrione a $<5 \%$, en todas las fechas. No se detectó daño en $F$. arundinacea en ninguna fecha de evaluación. En los experimentos de laboratorio, D. ischaemum alcanzó un pico de absorción foliar de ${ }^{14} \mathrm{C}$-mesotrione a 24 y $168 \mathrm{~h}$ después del tratamiento (HAT; 23\% y 15\%) cuando mesotrione fue aplicado con triclopyr a 0 y $1,120 \mathrm{~g} \mathrm{ha}^{-1}$, respectivamente. Triclopyr redujo la translocación de radioactividad $12 \%$ a $72 \mathrm{y}$ 168 HAT, al compararse con ${ }^{14} \mathrm{C}$-mesotrione solo. La mejora en la absorción foliar de mesotrione con las mezclas en tanque con triclopyr podría mejorar el control de $D$. ischaemum en el estadio de múltiples hijuelos al compararse con mesotrione solo. La reducción en el blanqueamiento foliar producto de triclopyr está asociada con una menor translocación de mesotrione o sus derivados en $D$. ischaemum.
\end{abstract}

DOI: $10.1614 /$ WT-D-15-00189.1

* Postdoctoral researcher and Associate Professor, Crop and Soil Sciences Department, University of Georgia, Griffin, GA 30223. Corresponding author’s E-mail: pmccull@uga.edu
Smooth crabgrass is a problematic annual weed in tall fescue. Turfgrass managers can reduce smooth crabgrass competition with tall fescue in summer by mowing lawns at $\geq 7.5-\mathrm{cm}$ height, improving 
drainage, and maintaining nutrients at sufficient levels for growth (Dernoeden et al. 1993; Hoyle et al. 2013). Cultural practices can reduce smooth crabgrass populations in tall fescue but herbicides are often needed to provide acceptable control. PRE herbicides, such as the dinitroanilines, bensulide, dithiopyr, or oxadiazon are used to prevent the establishment of smooth crabgrass in spring (Bhowmik 1987; Bhowmik and Bingham 1990; Johnson 1976). However, degradation of these herbicides in soil by late summer reduces efficacy for residual control of smooth crabgrass. Subsequent germination might warrant the use of POST herbicides to maintain acceptable turfgrass quality.

Turfgrass managers use acetyl CoA carboxylase (ACCase)-inhibitors, such as fenoxaprop and fluazifop, for POST control of smooth crabgrass in tall fescue. These herbicides do not control broadleaves and are antagonistic with phenoxy herbicides (Barnwell and Cobb 1994). Quinclorac, monosodium methylarsenate (MSMA), and ethofumesate provide early-POST control of smooth crabgrass in tall fescue and other turfgrass species. A major limitation to using these herbicides in tall fescue is erratic efficacy of single applications for controlling multitiller plants (Callahan 1986; Dernoeden et al. 2003; Johnson 1975; Wiecko and Couillard 1999). Moreover, the use of MSMA has been banned in residential lawns and athletic fields, which further limits the potential use in many tall fescue areas (US EPA 2013). Researchers have also reported resistance to ACCase-inhibitors and quinclorac in biotypes of smooth crabgrass from New Jersey and California, respectively (Abdallah et al. 2006; Derr 2002).

Mesotrione is a 4-hydroxyphenylpyruvate dioxygenase (HPPD) inhibitor that disrupts carotenoid biosynthesis in susceptible weeds (Mitchell et al. 2001). Foliar bleaching (whitening) can persist for approximately 2 wk after mesotrione treatments, followed by necrosis in susceptible species (Goddard et al. 2010). Applications from 175 to $280 \mathrm{~g}$ ai ha ${ }^{-1}$ provide PRE and POST control of smooth crabgrass before, during, or after tall fescue establishment (McCurdy et al. 2008; McElroy and Breeden 2007;). Mesotrione also offers an alternative mechanism of action to other herbicides labeled in tall fescue for resistance management. Foliar bleaching of smooth crabgrass from applications might be objectionable for intensively managed tall fescue lawns. Sequential applications of mesotrione are often required to control multitiller plants, which can extend the duration of foliar bleaching associated with smooth crabgrass control. These effects could preclude mesotrione use by end users who are concerned over the aesthetics of tall fescue lawns.

Triclopyr is a synthetic auxin herbicide used in tall fescue for POST broadleaf weed control. Researchers have reported that tank-mixing triclopyr with HPPD inhibitors reduces foliar bleaching of smooth crabgrass without compromising efficacy for control (Brosnan et al. 2013). In field experiments, triclopyr tank mixtures with HPPD inhibitors have been shown to improve smooth crabgrass control compared to applications of HPPD inhibitors alone (PE McCullough, personal observation). Use of sequential treatments of mesotrione for smooth crabgrass control is problematic because of greater application cost and extended foliar bleaching. Therefore, a single herbicide application that provided effective control and low foliar bleaching is preferred. The objectives of this research were to evaluate the influence of triclopyr on (1) mesotrione efficacy for smooth crabgrass control in tall fescue, as well as (2) absorption and translocation of ${ }^{14} \mathrm{C}$-mesotrione in smooth crabgrass.

\section{Materials and Methods}

Field Experiments. Experiments were conducted on an established 'Titan' tall fescue lawn at the University of Georgia Griffin Campus from July to September in both 2014 and 2015. Soil was a Cecil sandy clay loam (Fine, kaolinitic, thermic typic kanhapludults) with $6.2 \mathrm{pH}$ and $2.5 \%$ organic matter. The field was mowed weekly at a $7.5-\mathrm{cm}$ height with a rotary mower, and clippings were returned. Irrigation was applied as needed to prevent turfgrass wilting. The majority of the smooth crabgrass population in this tall fescue lawn had three or more tillers on the day of initial treatments in both years.

Mesotrione was applied once at $280 \mathrm{~g} \mathrm{ha}^{-1}$ or twice at $140 \mathrm{~g} \mathrm{ha}^{-1}$. Both mesotrione treatments were applied with triclopyr (Turflon Ester 4L, Dow AgroSciences, Indianapolis, IN 46268) at 0, 560, or $1,120 \mathrm{~g}$ ae $\mathrm{ha}^{-1}$. Fenoxaprop (Acclaim Extra 0.57EC, Bayer Environmental Sciences, Research 
Triangle Park, NC 27709) was applied at $195 \mathrm{~g}$ $\mathrm{ha}^{-1}$ as a standard comparison treatment. Application rates were chosen from labeled use rates of these herbicides in tall fescue (Anonymous 2008a,b, 2011). Treatments were applied with a $\mathrm{CO}_{2}$ pressured sprayer equipped with a single $9504 \mathrm{E}$ (TeeJet Spraying Systems Co., Roswell, GA 30075) flat-fan nozzle that delivered $374 \mathrm{~L} \mathrm{ha}^{-1}$ at $222 \mathrm{kPa}$. All treatments, except fenoxaprop, included a nonionic surfactant (Activator 90, 90\% alkylphenol ethoxylate and tall oil fatty acid, Loveland Products, Loveland, CO 80538) at $0.25 \% \mathrm{v} / \mathrm{v}$. The initial and sequential treatments were applied on July 1 and July 21 in 2014, respectively, and July 10 and July 31 in 2015, respectively.

Smooth crabgrass ground cover was visually evaluated on a percent scale where 0 equaled no cover and 100 equaled complete cover. Smooth crabgrass control was measured visually on a percent scale where 0 equaled no control and 100 equaled complete control. Foliar bleaching of smooth crabgrass and tall fescue were visually evaluated on a percent scale where 0 equaled no bleaching (whitening of leaves) and 100 equaled complete bleaching. Tall fescue injury was rated on a percent scale where 0 equaled no stunted growth and 100 equaled complete desiccation. Ratings were made every $7 \mathrm{~d}$ until $10 \mathrm{wk}$ after initial treatment (WAIT).

Laboratory Experiments. Experiments were conducted at the University of Georgia (Griffin, GA). Smooth crabgrass seed was collected by hand from indigenous plants in Griffin, GA and seeded into pots $(3.8-\mathrm{cm}$ diameter and $20-\mathrm{cm}$ depth) in a greenhouse set for day/night air temperatures of 32/ 25 C. Soil in these pots was a mixture of sand and peat moss $(85: 15 \mathrm{v} / \mathrm{v})$. Grasses received fertigation biweekly (MacroN 28-7-14 Sprayable Fertilizer, LESCO Inc., Cleveland, $\mathrm{OH}$ ) and were watered as needed to promote growth. Plants selected for inclusion in laboratory experiments were at a 3- to 5-tiller growth stage.

Smooth crabgrass was acclimated for $72 \mathrm{~h}$ before treatments in a growth chamber set for $32 / 25 \mathrm{C}$ (day/night) with a 12-h photoperiod. Plants were prepared for radiolabeled treatments by covering the third, fully expanded leaf with flexible film (Parafilm, Bemis Company Inc., Neenah, WI 54956). A broadcast treatment of mesotrione at $280 \mathrm{~g} \mathrm{ha}^{-1}$ with triclopyr at 0 or $1,120 \mathrm{~g} \mathrm{ha}^{-1}$ was applied with the aforementioned $\mathrm{CO}_{2}$-pressured sprayer calibrated to deliver $374 \mathrm{~L} \mathrm{ha}^{-1}$. The formulated herbicides and surfactant used in field experiments were applied for these treatments. The film was removed from the targeted leaf after broadcast treatment, and two $1-\mu \mathrm{L}$ droplets of ${ }^{14} \mathrm{C}$ mesotrione containing $150 \mathrm{~Bq}$ each were applied with a $10-\mu \mathrm{L}$ syringe. The spotting solution contained $0.75 \mu \mathrm{g} \mu \mathrm{L}^{-1}$ of mesotrione plus 0 or 3 $\mu \mathrm{g} \mu \mathrm{L}^{-1}$ of triclopyr to simulate droplets of spray solution. The nonionic surfactant was added to radiolabeled solutions at $0.25 \% \mathrm{v} / \mathrm{v}$.

Plants (roots plus shoots) were harvested at 1, 6, 24, 72, and $168 \mathrm{~h}$ after treatment (HAT). The treated leaf was excised and rinsed with $10 \mathrm{~mL}$ of methanol inside a $20-\mathrm{mL}$ scintillation vial. The base of the leaf was held with forceps, and rinsate was applied towards the leaf tip with a $5-\mathrm{mL}$ pipette on the leaf surface. This methodology was chosen from pilot experiments that completely removed adsorbed ${ }^{14} \mathrm{C}$ immediately after treatment (with and without triclopyr), and previous research with ${ }^{14} \mathrm{C}$-mesotrione on grain sorghum [Sorghum bicolor (L.) Moench.] (Abit and Al-Khatib 2009). Plants were then divided into four sections with shears, including: the treated leaf, all aboveground biomass except the treated leaf and tillers, tillers, and roots. The samples were then oven-dried for $14 \mathrm{~d}$ at $40 \mathrm{C}$.

Samples were combusted in a biological oxidizer and radioactivity was quantified with liquid scintillation spectroscopy (LSC; Beckman LS 6500 ${ }^{\circledR}$, Beckman Coulter Inc., Fall River, MA 02720). The entire plant was oxidized as one sample to calculate absorption over time from harvests at 1, 6, and 24 HAT. Plant parts were oxidized separately from harvests at 72 and 168 HAT to quantify radioactivity distribution. Methanol from rinsate was evaporated from vials in a forced-air hood, and radioactivity was quantified with LSC. Foliar absorption was quantified by dividing the total radioactivity recovered in plants by the total ${ }^{14} \mathrm{C}$ applied. Radioactivity distribution was determined by dividing the total radioactivity recovered in plant parts from the total ${ }^{14} \mathrm{C}$ recovered per plant. Radioactivity recovery was calculated by dividing the ${ }^{14} \mathrm{C}$ in rinsate and plant samples by the amount applied.

Experimental Design and Data Analysis. The design for the field experiments was a randomized 
Table 1. Smooth crabgrass foliar bleaching in tall fescue from herbicide treatments in field experiments, 2014 to 2015 , in Griffin, GA. Results were pooled over years.

\begin{tabular}{|c|c|c|c|c|c|c|c|c|c|c|c|c|}
\hline Application $^{a}$ & Treatment & Rate & \multicolumn{10}{|c|}{ Smooth crabgrass foliar bleaching (WAIT) ${ }^{\mathrm{b}}$} \\
\hline & & g ai ha ${ }^{-1}$ & & & & & & & & & & \\
\hline \multirow[t]{3}{*}{1} & Fenoxaprop & 195 & 0 & 0 & 0 & 0 & 0 & 0 & 0 & 0 & 0 & 0 \\
\hline & Mesotrione & 280 & 42 & 53 & 20 & 4 & 0 & 0 & 0 & 0 & 0 & 0 \\
\hline & Mesotrione + triclopyr & $280+560$ & 1 & 0 & 0 & 0 & 0 & 0 & 0 & 0 & 0 & 0 \\
\hline \multirow{3}{*}{2} & Mesotrione + triclopyr & $140+560$ & 2 & 0 & 0 & 0 & 0 & 0 & 0 & 0 & 0 & 0 \\
\hline & & $140+1,120$ & 2 & 0 & 0 & 0 & 0 & 0 & 0 & 0 & 0 & 0 \\
\hline & & $\mathrm{LSD}_{0.05}$ & 7 & 5 & 3 & 6 & 4 & 1 & NS & NS & NS & NS \\
\hline
\end{tabular}

${ }^{\text {a }}$ The initial and sequential treatments were applied on July 1 and July 21 in 2014, respectively. Initial and sequential treatments were applied on July 10 and July 31 in 2015, respectively.

b Abbreviations: NS, not significant; WAIT, weeks after initial treatment.

complete block with four replications of 0.9- by 3$\mathrm{m}$ plots. The plots in 2015 were adjacent to the plots in 2014. The design for the laboratory experiment was completely randomized with four replications, and the experiment was repeated.

Data were subjected to analysis of variance using the General Linear Model Procedure in SAS (SAS v. 9.3, SAS Institute Inc., Cary, NC 27513) and means were separated with Fisher's LSD test at $\alpha=$ 0.05 . For absorption data, regression analysis was performed after plotting means on graphs and selecting equations that characterized the relationship of foliar absorption over time. The equations used included the following linear (Equation 1) and two-parameter exponential (Equation 2) regression models:

$$
\begin{gathered}
y=\beta_{0}+\beta_{1}(x) \\
y=\beta_{0}+1^{*}\left(\exp \left(-\beta_{1}(x)\right)\right)
\end{gathered}
$$

where $y$ is percent foliar absorption, $x$ is time (hours after treatment), $\beta_{0}$ and $\beta_{1}$ are the intercept and slope for Equation 1, respectively, and $\beta_{0}$ and $\beta_{1}$ are the asymptote and slope for Equation 2, respectively. Standard errors and 95\% confidence limits were estimated for parameters in these equations. Experimental run-by-treatment interactions were not detected, and thus, results were pooled over runs for field and laboratory experiments.

\section{Results and Discussion}

Smooth Crabgrass and Tall Fescue Bleaching. The initial ground cover of smooth crabgrass measured 45\% ( \pm 0.9 standard error) and 35\% $( \pm 0.1)$ on the day of initial treatments in 2014 and 2015 , respectively. The single application of mesotrione at $280 \mathrm{~g} \mathrm{ha}^{-1}$ alone bleached smooth crabgrass 42 and $53 \%$ at 1 and 2 WAIT, respectively (Table 1). Bleaching declined to $20 \%$ at 3 WAIT, and measured $<5 \%$ from 4 to 10 WAIT. The sequential application of mesotrione at $140 \mathrm{~g} \mathrm{ha}^{-1}$ bleached smooth crabgrass 16 to $39 \%$ from 1 to 5 WAIT.

Splitting the mesotrione rate in two applications of $140 \mathrm{~g} \mathrm{ha}^{-1}$ reduced the initial degree of bleaching on two dates compared with the single treatment at $280 \mathrm{~g} \mathrm{ha}^{-1}$. However, foliar bleaching was extended for a longer period. By 4 WAIT, bleaching from the single and sequential treatment measured 4 and $22 \%$, respectively (Table 1 ). Smooth crabgrass bleaching declined to $<5 \%$ at 6 WAIT from mesotrione applied sequentially. Triclopyr tank mixtures with all single and sequential mesotrione applications reduced bleaching to $2 \%$ or less on all assessment dates. Differences in triclopyr rates at 560 and $1,120 \mathrm{~g} \mathrm{ha}^{-1}$ were not detected for smooth crabgrass bleaching. Tall fescue bleaching and injury was not detected from any treatment (data not shown).

Smooth Crabgrass Control. The single application of mesotrione at $280 \mathrm{~g} \mathrm{ha}^{-1}$ provided $20 \%$ greater control of smooth crabgrass than the $140 \mathrm{~g} \mathrm{ha}^{-1}$ 
Table 2. Smooth crabgrass control in tall fescue from herbicide treatments in field experiments, 2014 to 2015, in Griffin, GA. Results were pooled over years.

\begin{tabular}{|c|c|c|c|c|c|c|c|c|c|c|c|c|}
\hline \multirow[b]{2}{*}{ Application $^{a}$} & \multirow[b]{2}{*}{ Treatment } & \multirow[b]{2}{*}{ Rate } & \multicolumn{10}{|c|}{ Smooth crabgrass control (WAIT) ${ }^{\mathrm{b}}$} \\
\hline & & & 1 & 2 & 3 & 4 & 5 & 6 & 7 & 8 & 9 & 10 \\
\hline & & $\mathrm{g}$ ai ha ${ }^{-1}$ & & & & & - & & & & & \\
\hline \multirow[t]{4}{*}{1} & Fenoxaprop & 195 & 34 & 75 & 76 & 83 & 84 & 81 & 80 & 82 & 81 & 80 \\
\hline & Mesotrione & 280 & 35 & 61 & 68 & 69 & 71 & 66 & 63 & 60 & 59 & 47 \\
\hline & Mesotrione + triclopyr & $280+560$ & 45 & 90 & 91 & 94 & 92 & 91 & 89 & 89 & 90 & 85 \\
\hline & & $280+1,120$ & 46 & 92 & 92 & 93 & 96 & 93 & 93 & 92 & 91 & 87 \\
\hline \multirow[t]{4}{*}{2} & Mesotrione & 140 & 30 & 47 & 48 & 59 & 61 & 65 & 65 & 58 & 53 & 46 \\
\hline & Mesotrione + triclopyr & $140+560$ & 37 & 78 & 85 & 91 & 95 & 93 & 93 & 92 & 92 & 90 \\
\hline & & $140+1,120$ & 41 & 81 & 88 & 93 & 96 & 94 & 95 & 93 & 90 & 87 \\
\hline & & $\mathrm{LSD}_{0.05}$ & 7 & 5 & 7 & 7 & 7 & 8 & 7 & 7 & 7 & 6 \\
\hline
\end{tabular}

${ }^{\mathrm{a}}$ The initial and sequential treatments were applied on July 1 and July 21 in 2014, respectively. Initial and sequential treatments were applied on July 10 and July 31 in 2015, respectively.

${ }^{\mathrm{b}}$ Abbreviation: WAIT, weeks after initial treatment.

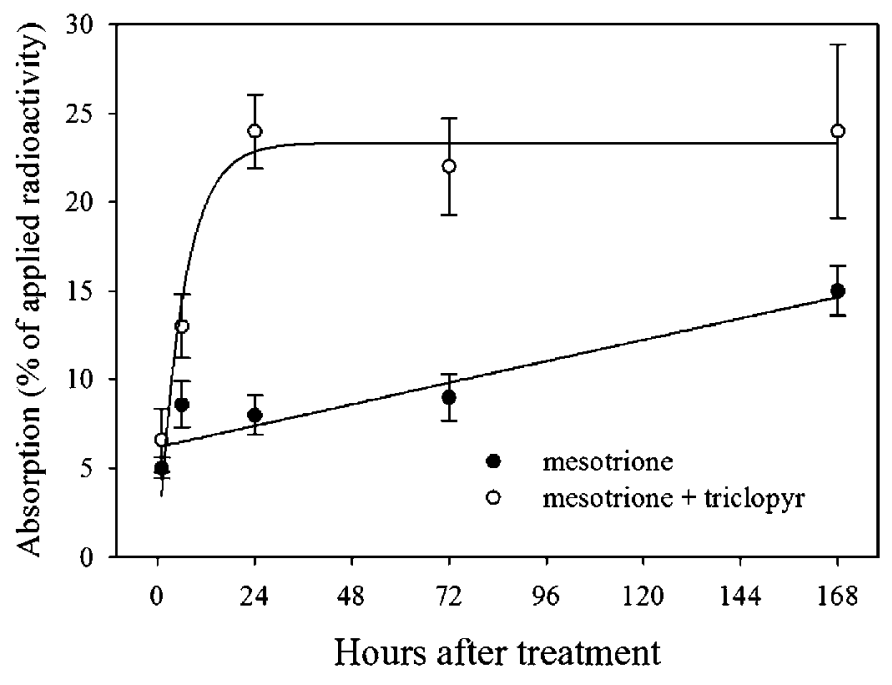

Figure 1. Foliar absorption of ${ }^{14} \mathrm{C}$-mesotrione in smooth crabgrass as influenced by triclopyr in two laboratory experiments. Mesotrione was applied at $280 \mathrm{~g} \mathrm{ha}^{-1}$ and triclopyr was applied at 0 or $1,120 \mathrm{~g}$ ae $\mathrm{ha}^{-1}$. Results were pooled over experimental runs. Standard errors of the mean are represented with vertical bars. Data for the mesotrione treatment were regressed with a linear model, $y=\beta_{0}+\beta_{1}(x)$, where $y$ is absorption, $\beta_{0}$ is the intercept, $\beta_{1}$ is the slope, and $\mathrm{x}$ is hours. Regression equation for mesotrione: $\mathrm{y}=6.3+0.05 \mathrm{x}, r^{2}=0.49$; standard errors for $\beta_{0}$ and $\beta_{1}$ were 0.7 and 0.01 , respectively; $95 \%$ confidence limits for $\beta_{0}$ and $\beta_{1}$ were 8.5 to 11.6 and 0.08 to 1.3 , respectively. Data for mesotrione + triclopyr were regressed with the following equation, $y=\beta_{0} *\left(1-\exp \left(-\beta_{1} *\right.\right.$ $\mathrm{x})$ ) where $\beta_{0}$ is the asymptote, $\beta_{1}$ is the slope estimate, and $\mathrm{x}$ is hours. Equation for mesotrione + triclopyr: $23.2 *(1-\exp$ $(-0.17 * \mathrm{x})), r^{2}=0.41$; standard errors for $\beta_{0}$ and $\beta_{1}$ were 1.8 and 0.2 , respectively; $95 \%$ confidence limits for $\beta_{0}$ and $\beta_{1}$ were 20 to 27 and 0.05 to 0.28 , respectively. treatment (68 vs. $48 \%$ control) at 3 WAIT (Table $2)$. The sequential application of the low rate improved control similar to the single application of $280 \mathrm{~g} \mathrm{ha}^{-1}$ from 6 to 10 WAIT. Sole use of mesotrione provided poor control (46 to 65\%) of smooth crabgrass on these dates regardless of application regimen.

The mesotrione plus triclopyr tank mixtures controlled smooth crabgrass $\geq 85 \%$ from 3 to 10 WAIT, and were more effective than mesotrione alone (Table 2). Smooth crabgrass was controlled by $91 \%$ from triclopyr plus mesotrione at $280 \mathrm{~g} \mathrm{ha}^{-1}$ at 2 WAIT, and was significantly greater than the low mesotrione rate applied with triclopyr $(80 \%$ control). However, the sequential treatments of mesotrione plus triclopyr improved smooth crabgrass control to $>90 \%$ from 4 to 9 WAIT. The tank mixtures of mesotrione plus triclopyr provided better smooth crabgrass control than fenoxaprop at $195 \mathrm{~g} \mathrm{ha}^{-1}$ (80 to $84 \%$ ) from 4 to 10 WAIT.

The reductions in foliar bleaching of smooth crabgrass by combining HPPD-inhibiting herbicide with triclopyr are consistent with previous research. Brosnan et al. (2013) found tank mixtures of topramezone and triclopyr resulted in less smooth crabgrass bleaching than topramezone alone. Smooth crabgrass control was not improved by using triclopyr with topramezone, but there were also no antagonistic effects on topramezone efficacy. Perhaps topramezone is more efficacious on multitiller smooth crabgrass than mesotrione, and therefore there is less potential for improving control with triclopyr. Further research is needed 
Table 3. Distribution of the absorbed radioactivity for smooth crabgrass treated with ${ }^{14} \mathrm{C}$-mesotrione and triclopyr in laboratory experiments. Results were pooled over experimental runs.

\begin{tabular}{|c|c|c|c|c|}
\hline & \multicolumn{4}{|c|}{${ }^{14} \mathrm{C}$ distribution } \\
\hline & Treated leaf $^{a}$ & Nontreated shoots ${ }^{\mathrm{b}}$ & Tillers & Roots \\
\hline & 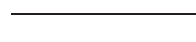 & $\%$ of absorbed ra & $\overline{-1}$ & 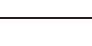 \\
\hline \multicolumn{5}{|c|}{ Triclopyr rate $\left(\mathrm{g}\right.$ ae $\left.\mathrm{ha}^{-1}\right)$} \\
\hline 0 & 72 & 11 & 13 & 4 \\
\hline 1,120 & 84 & 7 & 7 & 2 \\
\hline $\mathrm{LSD}_{0.05}$ & 7 & $N S^{c}$ & 3 & NS \\
\hline \multicolumn{5}{|c|}{ Hour after treatment (HAT) } \\
\hline 72 & 79 & 8 & 9 & 4 \\
\hline 168 & 77 & 11 & 10 & 2 \\
\hline $\mathrm{LSD}_{0.05}$ & NS & NS & NS & NS \\
\hline Triclopyr & $*$ & NS & * & NS \\
\hline HAT & NS & NS & NS & NS \\
\hline Triclopyr by HAT & NS & NS & NS & NS \\
\hline
\end{tabular}

to investigate the effect of application timing, rate, and growth stage on mesotrione efficacy for controlling smooth crabgrass with triclopyr.

Mesotrione is a potent inhibitor of HPPD enzymes, and the depletion of carotenoids results in cellular membrane peroxidation and chlorophyll degradation (Havaux 1998; Lee et al. 1997; Siefermann-Harms 1987; Trebst et al. 2002). Consequently, susceptible species exhibit foliar bleaching in the presence of light. We postulated that the addition of triclopyr could enhance damage to thylakoids and cellular membranes by mesotrione prior to chlorophyll degradation. Further research is needed to determine if the presence of triclopyr induces phytotoxicity from mesotrione that is independent of chlorophyll degradation and subsequent bleaching. This supposition, along with the effects of triclopyr alone on the carotenoid biosynthesis pathway, warrants further investigation with and without HPPD inhibitors.

${ }^{14} \mathrm{C}-$ Mesotrione Absorption and Translocation in Smooth Crabgrass. Harvest-by-triclopyr interaction was detected for foliar absorption of ${ }^{14} \mathrm{C}$ mesotrione. Recovery of the applied radioactivity averaged $79 \%( \pm 1.2)$. Smooth crabgrass absorption of mesotrione when applied alone increased linearly over time, and reached $15 \%$ of the applied radioactivity at $168 \mathrm{HAT}$ (Figure 1, Equation 1). The absorption rate was significantly increased when triclopyr was applied as a tank mixture with mesotrione. Peak foliar absorption of ${ }^{14} \mathrm{C}$-mesotrione was reached at $24 \mathrm{HAT}$ when tank-mixed with triclopyr, and the asymptote measured $23 \%$ $( \pm 1.8)$ of the applied radioactivity (Figure 1, Equation 2). Smooth crabgrass absorbed about four-fold more mesotrione in tank mixtures with triclopyr at $24 \mathrm{HAT}$, as compared to mesotrione alone. Mesotrione absorption levels plateaued at 24 $\mathrm{h}$ when applied with triclopyr, suggesting further uptake was inhibited due to rapid injury of smooth crabgrass.

Harvest-by-triclopyr interaction was not detected for radioactivity distribution; and thus, results were pooled over harvests (Table 3). Smooth crabgrass retained $72 \%$ of the absorbed radioactivity in the treated leaf when mesotrione was applied alone. The triclopyr and mesotrione tank mixture reduced translocation of radioactivity, compared to the exclusive mesotrione treatment, as $84 \%$ of the absorbed ${ }^{14} \mathrm{C}$ was retained in the treated leaf. The majority of the translocated radioactivity was recovered in nontreated shoots of the main plant and tillers. About 13\% of the absorbed radioactivity was translocated to nontreated tillers when mesotrione was applied alone. However, translocation was reduced to $7 \%$ when triclopyr was applied with mesotrione. Triclopyr did not reduce radioactivity 
translocation to nontreated shoots $(9 \%)$ of the main plant or roots $(3 \%)$.

Uptake and translocation of ${ }^{14} \mathrm{C}$-mesotrione have been studied in corn (Zea mays L.), Canada thistle [Cirsium arvense (L.) Scop.], common lambsquarters (Chenopodium album L.), giant foxtail (Setaria faberi Herrm.), ivyleaf morningglory (Ipomoea hederacea Jacq.), and soybean [Glycine max (L.) Merr.] (Armel et al. 2004, 2005; Mitchell et al. 2001). In corn, common lambsquarters, giant foxtail, and ivyleaf morningglory, foliar uptake was rapid, with 55 to $90 \%$ of applied radioactivity being absorbed within $24 \mathrm{~h}$ (Mitchell et al. 2001). However, the susceptible weeds had faster foliar absorption than the tolerant species, corn (Mitchell et al. 2001). Armel et al. (2005) found the greater susceptibility of Canada thistle to mesotrione at the rosette stage was associated with higher foliar absorption levels than plants at the bolting stage.

Alterations in absorption and translocation have been shown to improve the selectivity of other herbicides when applied with tank-mix partners. For example, Shaw and Wesley (1993) reported that acifluorfen and lactofen enhanced the absorption of ${ }^{14} \mathrm{C}$-chlorimuron and ${ }^{14} \mathrm{C}$-imazaquin, respectively, in common cocklebur (Xanthium strumarium L.), pitted morningglory (Ipomoea lacunosa L.), and prickly sida (Sida spinosa L.). Delrosario and Putnam (1973) reported that an insecticide, carbaryl, enhanced ${ }^{14} \mathrm{C}$-linuron penetration into carrot (Daucus carota L.) and parsnip (Pastinaca sativa L.) leaves compared to the herbicide alone.

Mesotrione exhibits acropetal and basipetal translocation after foliar absorption, but susceptible species have shown greater translocation of mesotrione than tolerant species (Armel et al. 2004; Mitchell et al. 2001). Tank mixtures that reduce this translocation pattern could be antagonistic with mesotrione or other HPPD inhibitors. In other species, Wehtje et al. (1993) found that 4-(2,4dichlorophenoxy) butyric acid (2,4-DB) significantly reduced translocation of radioactivity from ${ }^{14} \mathrm{C}$ chlorimuron in peanut (Arachis hypogaea L.), but enhanced ${ }^{14} \mathrm{C}$ translocation in Florida beggarweed [Desmodium tortuosum (Sw.) DC.]. Reductions in translocation of ${ }^{14} \mathrm{C}$-haloxyfop-methyl when tank mixed with bentazon, chlorimuron, or imazaquin in sorghum have also been reported (Croon et al. 1989).
Although triclopyr reduced the percentage of foliar-absorbed ${ }^{14} \mathrm{C}$-mesotrione translocation, the tank mixture enhanced the speed of mesotrione absorption by over six-fold. Perhaps any potential antagonistic effects that result from altered translocation by triclopyr are overcome by enhancing the speed of foliar absorption in smooth crabgrass. Additionally, enhanced foliar uptake of ${ }^{14} \mathrm{C}$-mesotrione when applied with triclopyr might result in greater herbicide concentrations in target tissues. Compounds associated with radioactivity translocation were not characterized, and it is unknown if translocation of the parent herbicide to tillers is affected by triclopyr. The degradation rate of mesotrione contributes to the differential tolerance levels of many species to applications (Mitchell et al. 2001). The addition of triclopyr could reduce mesotrione metabolism in smooth crabgrass, resulting in greater efficacy for control. Moreover, the formulated triclopyr ester herbicide was used to evaluate absorption for consistency with field experiments. Perhaps other triclopyr formulations might have different effects on mesotrione physiological behavior and efficacy. Therefore, further research is needed to investigate mesotrione efficacy, absorption, and metabolism as influenced by various formulations, rates, and salts of triclopyr that are available to end users.

\section{Implications for Enhancing Smooth Crabgrass}

Control. The addition of triclopyr enhances mesotrione efficacy for controlling multitiller smooth crabgrass in tall fescue. Smooth crabgrass bleaching was almost completely eliminated when triclopyr was included with mesotrione. These effects would be beneficial for end users concerned over reductions in turf aesthetics from the bleaching effects of mesotrione. Smooth crabgrass control was also improved from $\sim 65 \%$ by mesotrione alone, to greater than $90 \%$ when triclopyr was applied in tank mixtures. Enhanced control from the tank mixture is associated with faster foliar uptake of mesotrione when applied with triclopyr. Bleaching of crabgrass also can be minimized by reductions in translocation of mesotrione or derivatives by triclopyr. Overall, triclopyr alters the absorption and translocation of mesotrione in multitiller smooth crabgrass that results in better control and less foliar bleaching as compared to mesotrione alone. 


\section{Acknowledgments}

We would like to thank Luke Dant and J. R. James from Syngenta for providing radiolabeled mesotrione for this work.

\section{Literature Cited}

Abdallah I, Fischer AJ, Elmore CL, Saltveit ME, Zaki M (2006) Mechanism of resistance to quinclorac in smooth crabgrass (Digitaria ischaemum). Pestic Biochem Physiol 84:38-48

Abit MJM, Al-Khatib K (2009) Absorption, translocation, and metabolism of mesotrione in grain sorghum. Weed Sci 57:563-566

Anonymous (2008a) Tenacity Herbicide Label. Greensboro, NC: Syngenta Corp Protection, LLC. 8 p

Anonymous (2008b) Turflon Ester Herbicide Label. Indianapolis, IN: Dow AgroSciences, LLC. $3 \mathrm{p}$

Anonymous (2011) Acclaim Extra Herbicide Label. Research Triangle Park, NC: Bayer Crop Science. 3 p

Armel GR, Mayonado DJ, Hatzios KK, Wilson HP (2004) Absorption and translocation of SC-0051 in corn and soybean. Weed Technol 18:211-214

Armel GR, Hall GJ, Wilson HP, Cullen N (2005) Mesotrione plus atrazine mixtures for control of Canada thistle (Cirsium arvense). Weed Sci 53:202-211

Barnwell P, Cobb AH (1994) Graminicide antagonism by broadleaf weed herbicides. Pestic Sci 41:77-85

Bhowmik PC (1987) Smooth crabgrass (Digitaria ischaemum) control in Kentucky bluegrass (Poa pratensis) turf with herbicides applied preemergence. Weed Technol 1:145-148

Bhowmik PC, Bingham SW (1990) Preemergence activity of dinitroaniline herbicides used for weed control in cool-season turfgrasses. Weed Technol 4:387-393

Brosnan J, Breeden G, Patton A, Weisenberger D (2013) Triclopyr reduces smooth crabgrass bleaching with topramezone without compromising efficacy. Appl Turf Sci. DOI: $10.1094 / A T S-2013-0038-B R$

Callahan LM (1986) Crabgrass and goosegrass control in a bentgrass green in the transition zone. Agron J 78:625-628

Croon KA, Ketchersid ML, Merkle MG (1989) Effect of bentazon, imazaquin, and chlorimuron on the absorption and translocation of the methyl ester of haloxyfop. Weed Sci 37:645-650

DelRosario D, Putnam A (1973) Enhancement of foliar activity of linuron with carbaryl. Weed Sci 21:465-468

Dernoeden PH, Carroll MJ, Krouse JM (1993) Weed management and tall fescue quality as influenced by mowing, nitrogen, and herbicides. Crop Sci 33:1055-1061

Dernoeden PH, Bigelow CA, Kaminski JE, Krouse JM (2003) Smooth crabgrass control in perennial ryegrass and creeping bentgrass tolerance to quinclorac. HortScience 38:607-612

Derr JF (2002) Detection of fenoxaprop-resistant smooth crabgrass (Digitaria ischaemum) in turf. Weed Technol $16: 396-400$
Goddard MJ, Willis JB, Askew SD (2010) Application placement and relative humidity affects smooth crabgrass and tall fescue response to mesotrione. Weed Sci 58:67-72

Havaux M (1998) Carotenoids as membrane stabilizers in chloroplasts. Trends Plant Sci 3:147-151

Hoyle JA, Yelverton FH, Gannon TW (2013) Evaluating multiple rating methods utilized in turfgrass weed science. Weed Technol 27:362-368

Johnson B (1975) Postemergence control of large crabgrass and goosegrass in turf. Weed Sci 23:404-409

Johnson B (1976) Dates of herbicide application for summer weed control in turf. Weed Sci 24:422-424

Lee DL, Prisbylla MP, Cromartie TH, Dagarin DP, Howard SW, Provan WM, Ellis MK, Fraser T, Mutter LC (1997) The discovery and structural requirements of inhibitors of $\mathrm{p}$ hydroxyphenylpyruvate dioxygenase. Weed Sci 45:601-609

McCurdy JD, McElroy JS, Kopsell DA, Sams CE, Sorochan JC (2008) Effects of mesotrione on perennial ryegrass (Lolium perenne L.) carotenoid concentrations under varying environmental conditions. J Agric Food Chem 56:9133-9139

McElroy JS, Breeden GK (2007) Tolerance of turf-type tall fescue established from seed to postemergence applications of mesotrione and quinclorac. HortScience 42:382-385

Mitchell G, Bartlett DW, Fraser TEM, Hawkes TR, Holt DC, Townson JK, Wichert RA (2001) Mesotrione: a new selective herbicide for use in maize. Pest Manag Sci 57:120-128

Shaw DR, Wesley MT (1993) Interacting effects on absorption and translocation from tank mixtures of ALS-inhibiting and diphenylether herbicides. Weed Technol 7:693-698

Siefermann-Harms D (1987) The light-harvesting and protective functions of carotenoids in photosynthetic membranes. Physiol Plant 69:561-568

Trebst A, Depka B, Holländer-Czytko H (2002) A specific role for tocopherol and of chemical singlet oxygen quenchers in the maintenance of photosystem II structure and function in Chlamydomonas reinhardtii. FEBS Lett 516:156-160

[US EPA] U.S. Environmental Protection Agency (2013) Pesticide Reregistration: Organic Arsenicals. http://www2. epa.gov/ingredients-used-pesticide-products/monosodiummethanearsonate-msma-organic-arsenical. Accessed December 7, 2015

Wehtje GR, Wilcut JW, McGuire JA (1993) Absorption, translocation, and phytotoxicity of chlorimuron and 2, 4-DB mixtures in peanut (Arachis hypogaea) and selected weed species. Weed Sci 41:347-352

Wiecko G, Couillard A (1999) Sequential postemergence/ preemergence treatments for crabgrass control in bermudagrass turf. J Environ Hortic 17:103-106

Received December 12, 2015, and approved January 22, 2016.

Associate Editor for this paper: James Brosnan, University of Tennessee. 